Original Research

\title{
Evolutionary Game Study on the Development of Green Agriculture in China Based on Ambidexterity Theory Perspective
}

\author{
Herui Cui ${ }^{1}$, Tian Zhao ${ }^{1 *}$, Peijun Tao ${ }^{2}$ \\ ${ }^{1}$ Department of Economics and Management, North China Electric Power University, Baoding, Hebei, China \\ ${ }^{2}$ College of Agronomy, Hebei Agricultural University, Baoding, Hebei, China
}

Received: 9 January 2018

Accepted: 28 February 2018

\begin{abstract}
The traditional extensive agricultural production model has engendered grievous pollution, not meeting the Green Development Concept proposed by China. In this context, agricultural eco-innovation is born to alleviate environmental pressure and bring a novel production mode: green agriculture. Based on the ambidexterity theory, agricultural eco-innovation should not only realize the protection of the ecological environment, but also respect economic interests of various stakeholders in the process of agricultural production. In this paper, the marrow of ambidexterity theory in agricultural eco-innovation is expounded and the reason why green agriculture accords with it is proved by convincing representative cases. Considering the crucial crux restricting green agriculture is inefficient technology diffusion lying in both sides of the supply and demand of green technology, evolutionary game models between government and farmers, farmers and agricultural enterprises, are established to attempt to obtain the best stable strategy for better green technology diffusion. The game results indicate that it can be critical for slashing green production costs and enhancing returns on green production of farmers. Meanwhile reducing the supervision cost of government and strengthening the regulation of agricultural enterprises will be beneficial. Accordingly, policy recommendations are proposed to ensure green production in the whole agricultural production process.
\end{abstract}

Keywords: green agriculture, technology diffusion, evolutionary game, agricultural eco-innovation, ambidexterity theory

\section{Introduction}

Since the initiation of reform and opening up policy in the late 1970s, agriculture has developed rapidly in China, producing substantial economic benefits

*e-mail: hszt1991@163.com while being accompanied by grievous pollution and food safety issues mainly due to the immoderate use of fertilizer and pesticide [1,2]. More specifically, the amount of fertilizer application to land use in 1978 was 8.84 million tons, which has grown to 60.23 million tons in 2015, with approximately five times of net increase [3]. The pesticides and chemical fertilizers not absorbed entering the surrounding environment generate soil 
erosion and water pollution, even threatening human health and sustainable household livelihoods [4, 5]. Agricultural pollution has been one of the most severe environmental problems in China, accounting for half of the pollution emissions nation-wide [6, 7].

As a result, traditional extensive agriculture in the past is difficult to be sustained for achieving a winwin ecological and economic development. Especially China has formulated the Five Development Concept beginning in 2015, of which the Green Development Concept emphasizes special attention should be paid to protecting and improving the ecological environment while developing the economy [8]. Therefore, it is crucial to transform the agricultural development model to establish sustainable modern agriculture. Green agriculture, a new type of production and management mode of production, processing, and selling green agricultural products, with the concept of environmental friendliness, product health, and technological innovation [9], has proved to be a novel agricultural pattern with great advance prospects recently all over the world [10-15]. As green ideas are increasingly popular among the people, the country has paid more attention to advocating the development of green agriculture.

Specifically farmers and agricultural enterprises are actual implementers of agricultural production activities and the main competition of agricultural product market. They will be willing to accept the green production mode and control agricultural pollution if the ecological improvement and profitability maximization can both be considered, that is, the combination of ecooriented innovation and economic-oriented innovation for agricultural production. This development mode is called agricultural eco-innovation, with its noteworthy characteristics well incarnating the principle of ambidexterity theory $[16,17]$.

Ambidexterity theory originates from management, the focus of which is to explore contradiction and coexistence of two innovative activities, and refers to the realization of complement and balance in both economic development and ecological protection in the field of agricultural production [18-22]. As a new productive mode, it is proven that green agriculture perfectly accords with the ambidexterity theory attributed to its normative production standard, considerable revenue, advanced technology, recycled resource, agricultural livelihood improvement, and sustainable development [23-25], subject to the quintessence of agricultural ecoinnovation.

However, despite plenty of superiority in green agriculture, farmers and agricultural enterprises seem to be uninterested in accepting this revolutionary production and operation mode compared with conventional extensive agriculture patterns [26]. The conversion rate of agricultural scientific and technological achievements is only about $40 \%$ - far less than the level of nearly $80 \%$ in developed countries [27]. According to the relevant research, inefficient technology diffusion is the crux of this problem [28].

Technology diffusion is subsequent to technological innovation, meaning new technologies are adopted and commercially applied on a large scale [29]. Only when technological innovation is included in the general large-scale production process and effectively promoted and popularized can its potential economic benefits be fully exploited. Therefore, technology diffusion is to some extent more significant than technological innovation [30]. Previous researchers have studied the status quo of technology diffusion pertaining to green agriculture in China, concluding that an imperfect technology diffusion system [31], lack of demand for new technologies [32], and a weak technology popularization scheme $[33,34]$ are restricting diffusion of green farming technology.

To be specific, from the angle of the demander, i.e., farmers and enterprises, the reasons why they are unwilling to adopt green technology are as follows: 1) The traditional concept of cultivation is deeply rooted [35], 2) economic interests of farmers are not taken seriously because they lack the requisite scientific guidance of relevant green farming techniques [36], and 3) there exists the interest conflict about return allocation between farmers and agricultural enterprises in the green production process so that neither of them is ready to initiate green production [13, 37]. As the main promoter of green agriculture and supplier of green farming technology by related departments, the government also plays a critical role in poor performance of technology diffusion [34, 38]: 1) The government is deficient in enough financial subsidy of agricultural technology $R \& D$, 2) necessary supervision over agricultural production process is not adequate so that relevant producers are inclined to conduct illegal production, and 3) the implementation of relevant technology extension departments is not so perfect given the current status quo of agricultural production in China.

It is noted that, despite not only sources of pollution in agricultural production, but also the main body of technology diffusion, agricultural enterprises and farmers have poor subjective willingness of adopting green technology to carry out contamination control; at the same time, the government also fails to make its due contribution to regulation and supervision. This demonstrates that besides coercive measures from the government and moral constraints on producers, it is also necessary to consider increasing output to improve agricultural producers' livelihood to attain the dualpurpose of eco-oriented innovation and economicoriented innovation based on the ambidexterity theory, to make ecological protection also engender economic benefits for all parties in the diffusion process [39]. Few scholars have previously considered this issue from the perspective of ambidexterity theory.

Meanwhile, it can be also seen that farmers, agricultural enterprises, and governments are three important stakeholders in the process of green 
technology diffusion. The government attempts to guide farmers and enterprises in order to introduce green production technology and enforce implementation through various regulatory measures to accomplish the transformation of traditional production mode and the performance enhancement of preserving the environment; farmers and agricultural enterprises will determine whether to initiate green production based on the market environment, cost input, and mutual profit distribution. Each party abides by the principle of maximizing its own interests based on bounded rationality and incomplete information, which is suitable for applying evolutionary game theory (EGT) to decision-making analysis [40]. However, to the authors' best knowledge, there is few work that focuses on trying to solve this issue by EGT, except for several studies discussing the complete information static game between the government and farmers about green agricultural technology diffusion [41, 42], nevertheless neglecting the game between agricultural enterprises and farmers.

Therefore, to promote better progress of green agriculture in China in terms of technological diffusion for the purpose of food security and ecological harmony, while ensuring considerable outputs and earnings for all stakeholders from the perspective of ambidexterity theory, this work will be conducted from the following aspects to make a contribution to filling the gap in the existing studies. To begin with, we expound the marrow of ambidexterity theory in agricultural ecoinnovation. In addition, the relationship between green agriculture and ambidexterity theory is interpreted to prove why green agriculture is beneficial ecologically and economically. Second, evolutionary game models concerning farmers and government, and farmers and agricultural enterprises are established to obtain the dynamic evolution processes of their decisions on green agricultural technology diffusion, evolutionary stable strategies, and respective conditions. Finally, several beneficial recommendations on prompting green technology diffusion are given based on the above results.

In conclusion, this paper sheds light on the current studies in the following points: 1) It is the first try to apply the ambidexterity theory in the field of green agriculture development and explore their internal connection, which can provide a novel perspective for relevant studies; 2) distinguished from previous research, the evolutionary game framework is established to explore the diffusion of green agricultural technology among farmers, agricultural enterprises and government - especially since it is the first time that we consider the game between farmers and agricultural enterprises, from the perspective of green farming technology demanders; and 3) we propose a green technology diffusion circulation mechanism to ensure green production in the whole agricultural production process.

\section{The Ambidexterity Theory of Agricultural Eco-Innovation}

Distinct from other industries, agriculture is the only sector that can optimize natural ecosystems while using nature to generate economic benefits. This intertwined process of natural life and economic reproduction, making the agricultural production itself take into account both the economic-oriented and ecooriented innovation. Therefore, to realize the value of eco-innovation in agricultural production, it is crucial to comprehend the ambidexterity relationship between economic-oriented innovation and eco-oriented innovation, i.e., symbiosis and win-win [16, 43, 44].

\section{Symbiosis}

Broad symbiosis refers to energy conversion and material circulation among various organisms within the biosphere and external environment [45]. While in the field of agricultural eco-innovation, it can be categorized by three types: parasitic symbiosis, partial symbiosis, and reciprocal symbiosis [44], whose specific meanings can be shown in Table 1.

It can be seen that parasitic symbiosis and partial symbiosis are not in accordance with eco-innovation owing to their damage to economic interests or the environment. Only reciprocal symbiosis meets the eco-innovation because eco-oriented innovation and economic-oriented innovation benefit at the same time.

\section{Win-Win}

The win-win in eco-innovation can be manifested as the combination of balance dimension of ambidexterity and complementary dimension of ambidexterity [46]. More specifically, the balance dimension of

Table 1. Symbiosis modes of eco-innovation in agricultural production.

\begin{tabular}{|c|c|c|}
\hline Modes & Notes & Cases \\
\hline Parasitic symbiosis & $\begin{array}{c}\text { One party provides resources for the other, with one } \\
\text { benefited and one damaged. }\end{array}$ & $\begin{array}{c}\text { Farmers sacrifice yield to protect the ecological } \\
\text { environment. }\end{array}$ \\
\hline Partial symbiosis & $\begin{array}{c}\text { Both parties provide resources for each other, but } \\
\text { only one side benefits. }\end{array}$ & $\begin{array}{r}\text { The government introduces special funds to control } \\
\text { agricultural pollution. }\end{array}$ \\
\hline Reciprocal symbiosis & $\begin{array}{c}\text { Both parties benefit from providing resources for } \\
\text { each other. }\end{array}$ & $\begin{array}{c}\text { Green agriculture not only protects the environment } \\
\text { but also creates excess profit. }\end{array}$ \\
\hline
\end{tabular}


ambidexterity represents that economic-oriented innovation and eco-oriented innovation are equally significant. If we only emphasize economic-oriented innovation and neglect eco-oriented innovation, it may engender serious environmental pollution; but in turn, the mere emphasis on eco-oriented innovation may result in great loss of economic benefits, inefficient and unsustainable in agricultural production.

The complementary dimension of ambidexterity denotes the mutually beneficial relationship between economic-oriented innovation and eco-oriented innovation. On the one hand, economic-oriented innovation can promote eco-oriented innovation: 1) Economic-oriented innovation can create enduring returns and provide resources for producers to conduct eco-oriented innovation and 2) Economic-oriented innovation can enhance the knowledge reserve and management quality of producers, which in turn can progress implementation of eco-oriented innovation more smoothly and effectively. On the other hand, ecooriented innovation can also promote economic-oriented innovation: 1) The external effects of eco-oriented innovation (such as green-brand effects) can broaden the market business for green producers and generate excess profits and 2) With the gradual popularity of ecological concept, products and services produced by eco-oriented innovation can obtain a higher premium, so as to obtain more resources for economic-oriented innovation. According to the ambidexterity theory, this complementary relationship meets both the market demand and environmental requirements and can achieve the dual-purpose of green environment and considerable income.

\section{Relationship between Green Agriculture and Ambidexterity Theory}

The six essential characteristics of green agriculture put it in accord with ambidexterity theory [47-52]:

1. Normative production standard. Currently, there have been more than 100 green food standards at the national level. The amount of green food increasing from 12868 in 2006 to 14500 in 2014, and the number of certified green agriculture enterprises has achieved large-scale growth with the annual growth rate of $20.7 \%$ [53]. That production standards of green agricultural products are more stringent compared with ordinary food makes green food ensure not only the yield (economic-oriented innovation) but also the quality (eco-oriented innovation).

2. Considerable revenue. Agricultural products with green-brand can be sold at a quite higher price than before. Although the price is one to two times more expensive than ordinary produce, consumers are still willing to choose healthy green food.

3. Advanced technology. Green agriculture abandons the backward production technology to cause severe chemical pollution, moving steadily forward to the win-win production mode with a high-tech cultivation approach achieving simultaneous development of ecology and the economy.

4. Recycling of resources. For example, livestock manure can be used as bio-fertilizer and applied to grow organic crops, to form a green cycle mode as "livestock raising - excrement producing - manure fermenting - green fertilizer for crops." This pattern not only reduces the use of chemical fertilizer, but also improves production efficiency.

5. Livelihood improvement. With the flourish of green agriculture, more and more ecological family farms will be established to implement refined cultivation management for extra profits, absorbing a large number of rural surplus labor for employment.

6. Sustainability. Crop straw to the field for the use of gasification power generation, the human and livestock manure biogas project, biological bacteria fermentation bed to raise livestock, etc. - all of these are cutting-edge technologies of green agriculture having achieved positive economic, social, and environmental benefits.

It is clear to see that these virtues of green agriculture have a peculiarity in common: they not only bring excess profits to producers, but also protect the ecological environment; not only meeting the economic-oriented innovation, but also the eco-oriented innovation, which well conforms to the development concept of the ambidexterity theory in agricultural eco-innovation. Therefore, promoting the widespread diffusion of green agricultural technology plays the foremost role in building agricultural eco-innovation. Given aforementioned issues of inefficient technology diffusion and the fact that farmers, agricultural enterprises, and government all abide by the principle of maximizing their own interests, the EGT can provide a helpful approach in this context by defining a framework of contests, strategies, and analytical models.

\section{Evolutionary Game Model and Stability Analysis of the Evolution Strategy}

Based on the bounded rationality hypothesis and incomplete information, dynamic evolution processes of the research objective in the evolutionary game model is analyzed to interpret why and how the objective reaches its currently evolved state [54]. EGT distinguishes from classical game theory by focusing more on the dynamics of strategy change [55]. The core concepts of EGT are evolutionary stable strategy (ESS) and replicator dynamic [56]. Specific to issues of green agricultural technology diffusion in China, there exist two groups of evolutionary game model: the government and farmers, and farmers and agricultural enterprises. 
Table 2. Parameter definitions of the game model between government and farmers.

\begin{tabular}{|c|c|c|}
\hline Symbols & Stakeholders & Descriptions \\
\hline$C_{S}$ & \multirow{6}{*}{ Government } & The supervision cost \\
\hline$S$ & & Green technology risk subsidies for farmers \\
\hline$W$ & & Green technology buying allowances for farmers \\
\hline$P$ & & Penalties on farmers when the government finds they not adopting green farming technology \\
\hline$B$ & & The reputation promotion if agricultural ecosystem ameliorates due to green agriculture policy \\
\hline$C_{e}$ & & The environmental improvement cost when farmers adopt traditional production mode \\
\hline$R_{t}$ & \multirow{3}{*}{ Farmers } & Income from traditional production mode \\
\hline$C_{a}$ & & Additional cost for purchasing green farming technology \\
\hline$R_{a}$ & & Additional returns owing to green-brand effect \\
\hline
\end{tabular}

EGT Framework between the Government and Farmers

In the promotion of green agriculture, the government strives to guide farmers through various regulatory measures to achieve green production, while farmers will deliberate on whether to adopt green technology for transforming traditional production mode based on personal preference and the external environment. Hence, the government has two pure strategies: \{strict supervision, indolent supervision $\}$ and farmers also have two pure strategies: \{green production, traditional production\}. The definitions of variables used in this model are shown in Table 2.

Based on the above symbols, the payoff matrix can be built between the government and farmers, as shown in Table 3.

If the probability of strict supervision is $p$, then the indolent supervision accounts for 1-p; also, assuming that the probability of green production is $q$, the probability of traditional production is $1-\mathrm{q}(0 \leq \mathrm{p}, \mathrm{q} \leq 1)$. Assume that expected benefits of government choosing "strict supervision" and "indolent supervision" strategies are $U_{g 1}$ and $U_{g 2}$, respectively, which can be calculated as Eq. (1) and Eq. (2):

$$
U_{g 1}=q\left(B-C_{s}-S-W\right)+(1-q)\left(P-C_{s}-C_{e}\right)
$$

$$
U_{g 2}=-(1-q) C_{e}
$$

The average benefit of the government $\bar{U}_{g}$ can be computed as follows:

$$
\overline{U_{g}}=p U_{g 1}+(1-p) U_{g 2}
$$

Thus, based on the Malthusian dynamic equation [57], the replication dynamics equation for the government can be achieved by:

$$
\begin{gathered}
F(p)=\frac{d p}{d t}=p\left(U_{g 1}-\overline{U_{g}}\right)=p(1-p) \\
{\left[q(B-S-W-P)+P-C_{S}\right]}
\end{gathered}
$$

The expected benefits of farmers adopting "green production" and "traditional production" strategies are $U_{e 1}$ and $U_{e 2}$, respectively, which can be obtained by:

$U_{e 1}=p\left(R_{t}+R_{a}+S+W-C_{a}+(1-p)\left(R_{t}+R_{a}-C_{a}\right)\right.$

$$
U_{e 2}=p\left(R_{t}-P\right)+(1-p) R_{t}
$$

The average benefit for farmers $\bar{U}_{e}$ can be calculated as follows:

$$
\overline{U_{e}}=q U_{e 1}+(1-q) U_{e 2}
$$

The replicated dynamics equation for farmers can be achieved by:

$$
\begin{gathered}
F(q)=\frac{d q}{d t}=q\left(U_{e 1}-\overline{U_{e}}\right)=q(1-q) \\
{\left[p(S+W+P)+R_{a}-C_{a}\right]}
\end{gathered}
$$

Table 3. Payoff matrix of the game between the government and farmers.

\begin{tabular}{|c|c|c|c|}
\hline \multirow{2}{*}{\multicolumn{2}{|c|}{}} & \multicolumn{2}{|c|}{ Farmers } \\
\cline { 2 - 4 } & Strict supervision & $B-C_{S}-S-W, R_{t}+R_{a}+S+W-C_{a}$ & $P-C_{S}-C_{e}, R_{t}-P$ \\
\hline \multirow{3}{*}{ Government } & Indolent supervision & $0, R_{t}+R_{a}-C_{a}$ & $-C_{e}, R_{t}$ \\
\cline { 2 - 4 } & Iraditional production \\
\hline
\end{tabular}


Table 4. Local stability analysis of scenario 1.

\begin{tabular}{|c|c|c|c|}
\hline Equilibrium point & $\operatorname{det} J$ & $\operatorname{tr} J$ & Local stability \\
\hline $\mathrm{A}(0,0)$ & + & - & ESS \\
\hline $\mathrm{B}(0,1)$ & + & + & Unstable \\
\hline $\mathrm{C}(1,0)$ & - & \pm & Saddle point \\
\hline $\mathrm{D}(1,1)$ & - & \pm & Saddle point \\
\hline $\mathrm{E}\left(\mathrm{p}^{*}, \mathrm{q}^{*}\right)$ & + & 0 & Saddle point \\
\hline
\end{tabular}

On this occasion, the replicated dynamic state can be respectively achieved by making Eq. (4) and Eq. (8) equal to zero: $\mathrm{p}_{1}=0, \mathrm{p}_{2}=1, \mathrm{q}^{*}=\frac{\mathrm{C}_{\mathrm{S}}-\mathrm{P}}{\mathrm{B}-\mathrm{S}-\mathrm{W}-\mathrm{P}} ; \mathrm{q}_{1}=0$, $\mathrm{q}_{2}=1, \mathrm{p}^{*}=\frac{\mathrm{C}_{\mathrm{a}}-\mathrm{R}_{\mathrm{a}}}{\mathrm{S}+\mathrm{W}+\mathrm{P}}$. In conclusion, it can be obviously seen that there exist five equilibrium points in the system, namely, A $(0,0), \mathrm{B}(0,1), \mathrm{C}(1,0), \mathrm{D}(1,1)$, and $\mathrm{E}\left(\mathrm{p}^{*}, \mathrm{q}^{*}\right)$.

According to Friedman's theory [58], the stability of the dynamic system equilibrium point can be drawn from analyzing the local stability of Jacobian matrix of the system, which can be calculated by Eq. (9):

$$
J=\left[\begin{array}{ll}
\frac{\partial(d p / d t)}{\partial p} & \frac{\partial(d p / d t)}{\partial q} \\
\frac{\partial(d q / d t)}{\partial p} & \frac{\partial(d q / d t)}{\partial q}
\end{array}\right]=\left[\begin{array}{ll}
a_{11} & a_{12} \\
a_{21} & a_{22}
\end{array}\right]
$$

... where:

$$
\begin{gathered}
a_{11}=(1-2 P)\left[q(B-S-W-P)+P-C_{S}\right] \\
a_{12}=p(1-p)(B-S-W-P) \\
a_{21}=q(1-q)(S+W+P) \\
a_{22}=(1-2 q)\left[p(S+W+P)+R_{a}-C_{a}\right]
\end{gathered}
$$

So the determinant of Jacobian matrix is det $J=a_{11} a_{22}-a_{12} a_{21}$, and the trace of Jacobian matrix is $\operatorname{tr} J=a_{11}+a_{22}$. And if conditions meet the value of the balance point, $\operatorname{tr} J<0$, det $J>0$, the equilibrium point has local stability for the ESS at this point.

In order to simplify the analysis, we assume that $B>C_{S}+S+W$, because under the strict supervision,

Table 5 . Local stability analysis of scenario 2 .

\begin{tabular}{|c|c|c|c|}
\hline Equilibrium point & $\operatorname{det} J$ & $\operatorname{tr} J$ & Local stability \\
\hline $\mathrm{A}(0,0)$ & + & - & ESS \\
\hline $\mathrm{B}(0,1)$ & + & + & Unstable \\
\hline $\mathrm{C}(1,0)$ & + & + & Unstable \\
\hline $\mathrm{D}(1,1)$ & + & - & Saddle point \\
\hline $\mathrm{E}\left(\mathrm{p}^{*}, \mathrm{q}^{*}\right)$ & - & 0 & Saddle point \\
\hline
\end{tabular}

Table 6. Local stability analysis of scenario 3 .

\begin{tabular}{|c|c|c|c|}
\hline Equilibrium point & $\operatorname{det} J$ & $\operatorname{tr} J$ & Local stability \\
\hline $\mathrm{A}(0,0)$ & - & \pm & Saddle point \\
\hline $\mathrm{B}(0,1)$ & + & + & Unstable \\
\hline $\mathrm{C}(1,0)$ & + & - & ESS \\
\hline $\mathrm{D}(1,1)$ & - & \pm & Saddle point \\
\hline $\mathrm{E}\left(\mathrm{p}^{*}, \mathrm{q}^{*}\right)$ & + & 0 & Saddle point \\
\hline
\end{tabular}

the long-term social and environmental benefits gained by green production for government are enormous and greater than the sum of the cost the government has to pay for, including supervision cost and relevant subsidies. Meanwhile, $C_{a}>R_{a}$ is assumed for the reason that as development of green farming technology is still in its infancy, it will consume substantial manpower, material, and financial resources for farmers to transform extensive production mode to green mode. So at this period, the extra cost of green farming is greater than its extra income. According to the above assumptions, there exist four scenarios of the local stability analysis of the equilibrium point of this game.

Scenario 1. When $C_{S}>P$ and $C_{a}>R_{a}+S+W+P$, A $(0,0)$ is the only stable point of the system, that is, \{indolent supervision, traditional production\}, as shown in Table 4. The reason is that under this circumstance, the additional large cost for green production and scanty government subsidies for technology purchase and potential risk dampen the enthusiasm of farmers to carry out green production. Moreover, the penalty for farmers not engaged in green production is not enough to offset the large supervision costs paid by the government, with the passion of government regulation being also greatly reduced. Consequently, assistance from public opinion such as the media, the internet, and other nongovernment agencies can alleviate great cost pressure of government to supervise farmers on the selection of production mode.

Scenario 2. When $C_{S}>P$ and $C_{a}>R_{a}+S+W+P$,

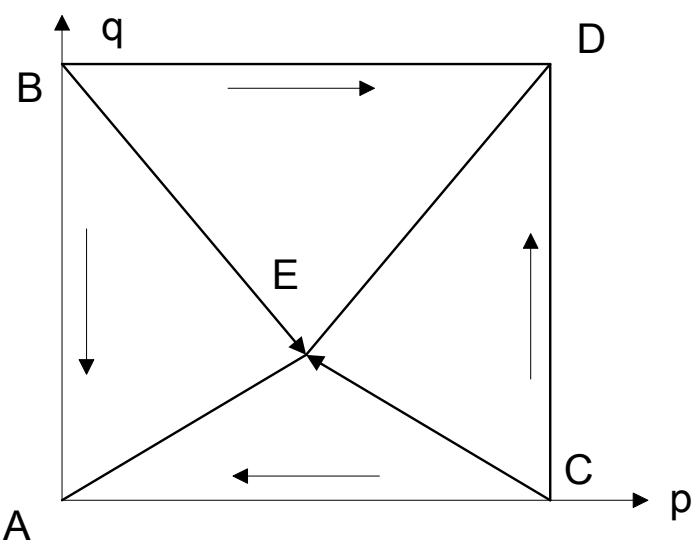

Fig. 1. Replicated dynamic diagram of scenario 2. 
Table 7. Local stability analysis of scenario 4 .

\begin{tabular}{|c|c|c|c|}
\hline Equilibrium point & $\operatorname{det} J$ & $\operatorname{tr} J$ & Local stability \\
\hline $\mathrm{A}(0,0)$ & - & \pm & Saddle point \\
\hline $\mathrm{B}(0,1)$ & + & + & Unstable \\
\hline $\mathrm{C}(1,0)$ & - & \pm & Saddle point \\
\hline $\mathrm{D}(1,1)$ & + & - & ESS \\
\hline $\mathrm{E}\left(\mathrm{p}^{*}, \mathrm{q}^{*}\right)$ & - & 0 & Saddle point \\
\hline
\end{tabular}

there are two stable strategies: \{strict supervision, green production $\}$ and \{indolent supervision, traditional production\}, as shown in Table 5. In this case, farmers receive more subsidies than before, which can offset their green production cost to a certain degree. The evolutionary phase diagram of the system evolution is shown in Fig. 1, and the final evolution result depends on the initial state of the system. To increase the occurrence probability of the perfect sable strategy, \{strict supervision, green production\}, the ratio of area $\mathrm{C}-\mathrm{E}-\mathrm{B}-\mathrm{D}$ to area A-B-E-C should be as large as possible, that is, the value of $\mathrm{p}^{*}$ and $\mathrm{q}^{*}$ should be smaller to make saddle point $\mathrm{E}$ move to the left bottom direction. Hence, it will be helpful to reduce government supervisory cost, increase penalties for farmers, provide enough technology risk and purchase subsidies, and enhance additional returns of farmers from green-brand effects.

Scenario 3. When $B<S+W+P$ and $C_{a}>R_{a}+S+W+P$, the stable strategy is strict supervision, traditional production $\}$, as shown in Table 6. Under this condition, although penalties are large enough for adopting traditional farming technology, the risk subsidies and technology purchase allowances for farmers engaged in green agriculture are relatively fewer, and they still prefer traditional agricultural technologies.

Scenario 4. When $B<S+W+P$ and $C_{a}<R_{a}+S+W+P$, the best stable strategy can be obtained, i.e. \{strict supervision, green production\}, as shown in Table 7. In this case, farmers have to employ green agricultural technology to avoid enormous penalties from quite strict supervision from government.
To promote the occurrence of this strategy, from the perspective of government, the supervision should be strengthened by making full use of participation of technology diffusion agencies to assist the government in reducing supervision cost; meanwhile, the power of the media should be used to increase the reputation of government for its endeavor to fulfill eco-innovation to increase regulatory revenue. From the perspective of farmers, besides propaganda of green production awareness, relevant green production cost including purchasing green technologies, equipment and other production materials and professional introduction should be slashed dramatically and additional benefits of green production should be increased through some preferential policies at the same time.

\section{EGT Framework between Agricultural Enterprises and Farmers}

In the current "agricultural enterprises + farmers" production model in China, agricultural enterprises are usually the leading decision-makers, properly organizing and guiding the participation of farmers, and farmers are the specific executors for agricultural production. Throughout the green production technology diffusion, agricultural enterprises and farmers are a group of stakeholders with a complex relationship attributed to co-existence of cooperation and conflict for respective interests. Due to tremendous disparities in economic strength and resource possession on both sides, on the one hand most agricultural enterprises are in pursuit of economic interests, not giving full consideration to the interests of farmers; on the other hand, farmers prefer selecting traditional extensive mode because they merely desire increasing employment opportunities and improving their economic conditions.

Under the development policy of green agriculture, in order to ensure green production in the whole agricultural process, enterprises and farmers will have to reach an agreement on the effective implementation of green agriculture. Based on the agreement signed, farmers actualize green production under the guidance of green technologies provided by enterprises, while agricultural enterprises allocate part of the benefits

Table 8. Parameter definitions of the game model between agricultural enterprises and farmers.

\begin{tabular}{|c|c|c|}
\hline Symbols & Stakeholders & Descriptions \\
\hline G & \multirow{4}{*}{$\begin{array}{c}\text { Agricultural } \\
\text { enterprises }\end{array}$} & Green income allocated to farmers \\
\hline$D_{g}$ & & Decreased production cost when farmers implement green production according to the agreement \\
\hline$L_{g}$ & & Economic loss if farmers breach the agreement on green production \\
\hline$F_{g}$ & & $\begin{array}{l}\text { Penalties on enterprises from the government when farmers find they not obtaining deserved green income } \\
\text { as they implement green production }\end{array}$ \\
\hline$R_{g}$ & \multirow{3}{*}{ Farmers } & Returns from green agricultural mode from brand effect, reputation enhancement and quality improvement \\
\hline$C_{g}$ & & Additional cost for green production including purchasing relevant technology and learning cost \\
\hline$P_{b}$ & & Liquidated damages when breaching the agreement on green production \\
\hline
\end{tabular}


Table 9. Payoff matrix of the game between agricultural enterprises and farmers.

\begin{tabular}{|c|c|c|c|}
\hline \multirow{2}{|c|}{} & \multicolumn{2}{|c|}{ Farmers } \\
\cline { 2 - 3 } & Green production & Traditional production \\
\hline \multirow{3}{*}{ Agricultural enterprises } & Distribute green income & $D_{g}-G, R_{g}+G-C_{g}$ & $P_{b}-G-L_{g}, G-P_{b}$ \\
\cline { 2 - 4 } & Monopolize green income & $D_{g}-F_{g}, R_{g}+F_{g}-C_{g}$ & $-L_{g}, 0$ \\
\hline
\end{tabular}

brought by green production to farmers. However, due to the asymmetric information, enterprises may not allocate deserved benefits to farmers who adopt green technology in order to implement eco-innovation in agricultural production. In turn, farmers may also not be able to enforce themselves on green production according to rules for their own interests. Consequently, agricultural enterprises have two pure strategies: \{distribute green income, monopolize green income\} and farmers also have two pure strategies: \{green production, traditional production\}. The definitions of variables used in this evolutionary game model are shown in Table 8.

Therefore, the payoff matrix of the evolutionary game model between agricultural enterprises and farmers is shown in Table 9.

Let $\mathrm{x}$ be the probability of the strategy that enterprises distribute green income, with 1-x being the probability of green income monopoly by agricultural enterprises; similarly, $y$ represents the probability of green production by farmers, and 1-y refers to the probability of traditional production, where $\mathrm{x}, \mathrm{y}$ satisfy the condition of $0 \leq x, y \leq 1$. Based on the approach aforementioned in the evolutionary game model between the government and farmers, the replication dynamics equation of agricultural enterprises is therefore:

$$
F(x)=\frac{d x}{d t}=x(1-x)\left[y\left(F_{g}-P_{b}\right)+P_{b}-G\right]
$$

While the replication dynamics equation of farmers is:

$$
F(y)=\frac{d y}{d t}=y(1-y)\left[x\left(P_{b}-F_{g}\right)+R_{g}+F_{g}-C_{g}\right]
$$

There are five local equilibrium points when the replicator dynamics equation is equal to $0: A_{1}(0,0), B_{1}$ $(0,1), \mathrm{C}_{1}(1,0), \mathrm{D}_{1}(1,1)$, and $\mathrm{E}_{1}\left(\left(R_{g}+F_{g}-C_{g}\right) /\left(F_{g}-P_{b}\right)\right.$, $\left.\left(G-P_{b}\right) /\left(F_{g}-P_{b}\right)\right)$. The Jacobian matrix is:

$$
J=\left[\begin{array}{ll}
\frac{\partial(d x / d t)}{\partial x} & \frac{\partial(d x / d t)}{\partial y} \\
\frac{\partial(d y / d t)}{\partial x} & \frac{\partial(d y / d t)}{\partial y}
\end{array}\right]=\left[\begin{array}{ll}
b_{11} & b_{12} \\
b_{21} & b_{22}
\end{array}\right]
$$

...where:

$$
\begin{gathered}
b_{11}=(1-2 x)\left[y\left(F_{g}-P_{b}\right)+P_{b}-G\right] \\
b_{12}=x(1-x)\left(F_{g}-P_{b}\right) \\
b_{21}=y(1-y)\left(P_{b}-F_{g}\right) \\
b_{22}=(1-2 y)\left[x\left(P_{b}-F_{g}\right)+R_{g}+F_{g}-C_{g}\right]
\end{gathered}
$$

In each equilibrium point, the determinant and trace of the Jacobian matrix are shown in Table 10.

Before further analysis, $P_{b}<G<F_{g}$ is assumed based on the reality, that is the liquidated damages paid by farmers are less than the green income they get, and penalties for green income monopoly by enterprises are greater than the green income they allocated. Only in this condition can the game make sense, otherwise there is no possibility of cooperation between farmers and agricultural enterprises. Accordingly, as shown in Table 7, symbols of $R_{g}+F_{g}-C_{g}$ and $R_{g}+P_{b}-C_{g}$ need to be determined. As a result, three cases of local stability of the equilibrium point of this game should be discussed as follows.

Case 1. If $C_{b}<R_{S}+P_{b}$, either green benefits obtained by farmers or liquidated damages from their traditional

Table 10. Values of the $\operatorname{det} J$ and $\operatorname{tr} J$ for the game between agricultural enterprises and farmers.

\begin{tabular}{|c|c|c|}
\hline Equilibrium Point & $\operatorname{det} J$ & $\operatorname{tr} J$ \\
\hline $\mathrm{A}(0,0)$ & $\left(P_{b}-G\right)\left(R_{g}+F_{g}-C_{g}\right)$ & $P_{b}-G+R_{g}+F_{g}-C_{g}$ \\
\hline $\mathrm{B}(0,1)$ & $\left(G-F_{g}\right)\left(R_{g}+F_{g}-C_{g}\right)$ & $C_{g}-G-R_{g}$ \\
\hline $\mathrm{C}(1,0)$ & $\left(G-P_{b}\right)\left(R_{g}+P_{b}-C_{g}\right)$ & $G+R_{g}-C_{g}$ \\
\hline $\mathrm{D}(1,1)$ & $\left(F_{g}-G\right)\left(R_{g}+P_{b}-C_{g}\right)$ & $G-F_{g}-R_{g}-P_{b}+C_{g}$ \\
\hline $\mathrm{E}\left(\mathrm{p}^{*}, \mathrm{q}^{*}\right)$ & $\frac{\left(G-F_{b}\right)\left(R_{g}+F_{g}-C_{g}\right)\left(G-P_{b}\right)\left(R_{g}+P_{b}-C_{g}\right)}{\left(F_{g}-P_{b}\right)^{2}}$ & 0 \\
\hline
\end{tabular}


Table 11. Local stability analysis of Case 1.

\begin{tabular}{|c|c|c|c|}
\hline Equilibrium point & $\operatorname{det} J$ & $\operatorname{tr} J$ & Local stability \\
\hline $\mathrm{A}_{1}(0,0)$ & - & \pm & Saddle point \\
\hline $\mathrm{B}_{1}(0,1)$ & - & \pm & Saddle point \\
\hline $\mathrm{C}_{1}(1,0)$ & + & + & Unstable \\
\hline $\mathrm{D}_{1}(1,1)$ & + & - & ESS \\
\hline $\mathrm{E}_{1}\left(\mathrm{p}^{*}, \mathrm{q}^{*}\right)$ & - & 0 & Saddle point \\
\hline
\end{tabular}

Table 12. Local stability analysis of Case 2.

\begin{tabular}{|c|c|c|c|}
\hline Equilibrium point & $\operatorname{det} J$ & $\operatorname{tr} J$ & Local stability \\
\hline $\mathrm{A}_{1}(0,0)$ & - & \pm & Saddle point \\
\hline $\mathrm{B}_{1}(0,1)$ & - & \pm & Saddle point \\
\hline $\mathrm{C}_{1}(1,0)$ & - & \pm & Saddle point \\
\hline $\mathrm{D}_{1}(1,1)$ & - & \pm & Saddle point \\
\hline $\mathrm{E}_{1}\left(\mathrm{p}^{*}, \mathrm{q}^{*}\right)$ & + & 0 & Saddle point \\
\hline
\end{tabular}

production are quite large, the sum of which can offset extra green production cost for farmers. Therefore, the system is eventually evolved to promote farmers to take the initiative to choose green production and agricultural enterprises to be willing allocate green income, i.e., the best stable strategy of the game, ddistribute green income, green production $\}$. $\mathrm{D}_{1}(1,1)$ is the only stable point of the system, as shown in Table 11.

Case 2. If $C_{g}>R_{S}+P_{b}$ and $C_{b}<R_{S}+F_{g}$, the additional cost for green production of farmers is greater than the sum of their green benefit and liquidated damages implementing traditional production, and is less than the sum of farmers' green benefit and compensation received form enterprises when they monopolize green income. So the strategy choice of both sides is uncertain with no stable point, as shown in Table 12. For spurring the system to evolve to $D_{1}(1,1)$, the best stable strategy of the game, it will be effective to increase fines of unruly agricultural enterprises and reduce the cost of green production of farmers.

Case 3. If $C_{g}>R_{g}+F_{g}, \mathrm{~A}_{1}(0,0)$ is the only stable point of the system, with the local stability analysis of this case being shown in Table 13. On this occasion, the

Table 13. Local stability analysis of Case 3.

\begin{tabular}{|c|c|c|c|}
\hline Equilibrium point & $\operatorname{det} J$ & $\operatorname{tr} J$ & Local stability \\
\hline $\mathrm{A}_{1}(0,0)$ & + & - & ESS \\
\hline $\mathrm{B}_{1}(0,1)$ & + & + & Unstable \\
\hline $\mathrm{C}_{1}(1,0)$ & - & \pm & Saddle point \\
\hline $\mathrm{D}_{1}(1,1)$ & - & \pm & Saddle point \\
\hline $\mathrm{E}_{1}\left(\mathrm{p}^{*}, \mathrm{q}^{*}\right)$ & + & 0 & Saddle point \\
\hline
\end{tabular}

additional benefits that farmers fulfill green production or penalties for the non-distribution of green income by the agricultural enterprises are small, and the sum of those is less than the extra cost of green agriculture production for farmers, so that farmers would rather pay the liquidated damages than implement green production. Hence, \{monopolize green income, traditional production\} becomes the worst stable strategy of the system for the purpose of green agricultural technology diffusion and achieving eco-innovation in agricultural production.

Consequently, effective measures should be taken to slash green production cost and enhance the returns on green production of farmers, such as transformation of production concept, free training on green cultivation techniques for farmers, and providing or improving modern agricultural production facilities.

\section{Conclusions}

Currently, the Green Development Concept represented by eco-innovation, giving consideration to both eco-oriented innovation and economic-oriented innovation, has become the hot spot of transformation and upgrading of development mode in China. In this paper, eco-innovation in agriculture is paid attention from the perspective of ambidexterity theory, which takes account of symbiosis and win-win relations in the process of agricultural production, that is, the coordinated development of economic growth and environmental protection. Numerous examples have proven that green agriculture is the perfect modern agricultural production mode, according with the marrow of ambidexterity theory in agricultural ecoinnovation. Given the poor status quo of green production technology diffusion from both supply side and demand side, an EGT framework between the government and farmers as well as farmers and agricultural enterprises, the three main stakeholders in the promotion of green agriculture, is established to attempt to obtain the method to the best stable strategy for better green production technology diffusion. Based on results of the above evolutionary game models, several instructive conclusions have emerged.

From the perspective of the game between government and farmers, as the main promoter of ecoinnovation development mode, the government performs a vital role in the diffusion of green agricultural technologies, of which supervision is crucial for guiding farmers to implement green production, the key to guaranteeing the smooth development of green agriculture. According to the result, if the governmental supervision effort is weak, ascribed to the penalty for farmers not engaged in green production being not enough to offset large supervision cost paid by government, the stable strategy is \{indolent supervision, traditional production $\}$. Therefore, the government can 
diminish great supervision cost with the power of the media, the internet, and other non-government agencies to assist in supervising farmers on the selection of production mode. At the same time, a good social atmosphere of public opinion should be established so that the government can gain a beneficial reputation in order to encourage the government to step up its supervision.

As for farmers, whether they accept environmentally friendly technology to implement green agricultural production is mainly affected by green production cost, additional benefits from green agriculture, and government supervision. And farmers will be inclined to adopt extensive production mode with less cost and more short-term returns. Accordingly, the government should increase penalties for farmers carrying out traditional production secretly as a warning, meanwhile giving reasonable financial subsidies for green product and purchase discount of green farming technology. Further, it is necessary to increase green agriculture propaganda to boost the brand effect of green agricultural products. In summary, the government should take various measures to guide and help farmers better actualize green farming production.

From the perspective of the game between agricultural enterprises and farmers, the system will evolve to the best strategy ddistribute green income, green production\} when the sum of green benefits obtained by farmers and liquidated damages from their traditional production can offset extra green production cost for farmers. Hence, in the "agricultural enterprises + farmers" productive model, it is of crucial significance to enhance the allocation of green returns to farmers, strengthen the productive management of farmers, and ensure reasonable allocation of green income according to relevant agreement. Specifically, agricultural enterprises can positively instruct farmers about green production technology and help improve the infrastructure construction agricultural production to assist farmers with production risk relief and technology cost reduction. More importantly, agricultural enterprises should fully take into account the immediate interests of farmers, and guarantee that their due benefits are not compromised.

As can been seen above, it is apparent to see farmers play the foremost role in green farming technology diffusion to establish agricultural eco-innovation, because for one thing, farmers are the specific implementers and producers in green agriculture; for another thing, based on ambidexterity theory, the economic interest of farmers should be protected effectively considering their weak position during the development of green agriculture. Moreover, a series of subsidy policy from the government and instruction in green farming knowledge and amelioration of production facilities can enhance the enthusiasm of farmers for initiating eco-innovation. As a result, the government, farmers, and agricultural enterprises should make concerted efforts to strive for the win- win progress of all three parties and the sustainable development of green agriculture.

\section{Policy Recommendations}

For accomplishing the aim to build ecological civilization based on the Green Development Concept [8], relevant measures forming a green technology diffusion circulation mechanism are proposed in order to ensure green production in the whole agricultural production process, on the basis of aforementioned conclusions from following three aspects:

1: Before green production

In the first place, the diffusion of the green farming concept should be developed by the government through efficient dissemination using the power of all sectors of society. It is vital to strengthen green awareness of related producers and improve their quality and skill so that they are willing to implement green production by appropriate behavior daily. It is also critical to foster and train professional agricultural technical personnel vigorously to be prepared theoretically for the diffusion of green technology, and at the same time to promote the collaborative innovation of research institutions and leading agricultural enterprises. In addition, there is an urgent need regarding supporting policies to establish a legislative protection system and green food production standards for the purpose of green production employees not suffering unexpected losses such as technological risk and market uncertainty.

2: Process of green production

To begin with, the local government should scientifically and timely adjust green production structures to fit the actual market situation in order to guarantee the orderly development of green agriculture. It is necessary to provide respectable discounts to farmers for purchasing related products in the farming process such as green fertilizers and pesticides. As for agricultural enterprises that regularly contact the agricultural scientific research institutions and organize practical technical guidance to green farming by professionals will make sense to expand the application of innovations to rural areas. The internet plus mode can be taken advantage of establishing "farmer + agricultural enterprise + research institution" interactive online platforms for providing real-time technical queries and training, as well as revealing market dynamics of agricultural produce and profit and loss situations. Furthermore, it will be beneficial to advance the agency of agricultural technology extension and offer a complete set of services such as information consulting, financial accounting, and legal advice, which will not only reduce relevant management costs but also help maintain deserved interest of all stakeholders in the promotion of green agriculture.

3: After green production

First, the efficient agricultural "Internet of Things" (IOT) should be built to perfect the green food supply 
chain, making production and marketing integration, which can not only transport agriculture products with distinctive green features efficiently but also ensure it is an environmentally friendly process. Second, the establishment of a supervision and management agency of agricultural products is essential to monitoring the quality of agricultural products. Once relevant products are found to be not in accordance with green standards, the source of responsibility must be ascertained to improve the whole system of the traceability mechanism. In addition, in order to focus on green-brand strategy and establish a demonstration production base establishing model effect, we can realize the diffusion of green technology better. At last, green production cases of every pilot place should be summarized, learning from respective experiences and lessons, and it will be helpful to absorb the valuable experience of the overseas diffusion of green technology at the same time.

\section{Acknowledgements}

This work was supported by the National Social Science Foundation of China (No. 15BGL145) and the National Natural Science Foundation of China (No. 71471061).

\section{Conflict of Interest}

The authors declare no conflict of interest.

\section{References}

1. ZHENG S.Z., XIAO M.H., MIAO Z. M. Nitrogen Losses in Paddy Field Drainage Modified by Different Water Level Regulations. Polish Journal of Environmental Studies, 26 (3), 1393, 2017.

2. YOU H.Y., ZHANG X.L. Ecoefficiency of Intensive Agricultural Production and Its Influencing Factors in China: An Application of DEA-Tobit Analysis. Discrete Dynamics in Nature and Society, 2016, 12016.

3. National Bureau of Statistics of China. China Statistical Yearbook of 2016. China Statistics Press, Beijing. 2016.

4. WANG Y., SHEN N. Agricultural Environmental Efficiency and Agricultural Environmental Kuznets Curve Based on Technological Gap: the Case of China. Polish Journal of Environmental Studies, 25 (3), 1293, 2016.

5. LI J., RODRIGUEZ D., TANG X.Y. Effects of land lease policy on changes in land use, mechanization and agricultural pollution. Land Use Policy, 64, 405, 2017.

6. YOU H.Y. Impact of urbanization on pollution-related agricultural input intensity in Hubei, China. Ecological Indicators, 62, 249, 2016.

7. EDWIN D.O., ZHANG X.L., YU T. Current status of agricultural and rural non-point source Pollution assessment in China. Environmental Pollution, 158 (5), 1159, 2010.

8. XINHUANET. Five Development Concept leading the development of China. Retrieved November 12,
2017, from http://news.xinhuanet.com/politics/201511/16/c_128433822_2.htm 2015.

9. PARVIZ K., MIGUEL A.A., ERIC H.G. Green Agriculture: Foundations for biodiverse, resilient and productive agricultural systems. International Journal of Agricultural Sustainability, 10 (1), 61, 2012V

10. HU X.P., DONG H.T. Obstacles and path selection about the construction of green agricultural investment and financing mechanism. China Population Resources and Environment, 25 (6), 152, 2015.

11. DENG W., CHEN L.P., MENG Z., WU G.W., ZHANG R.R. Review of non-chemical weed management for green agriculture. International Journal of Agricultural and Biological Engineering, 3 (4), 52, 2010.

12. QIN L., QI Y. Analysis on green agriculture policy during the development of eco-city in European countries and the United States and policy recommendations. Asian Agricultural Research, 6 (8), 18, 2014.

13. ALLAHYARI M.S. Reorganization of agricultural extension toward green agriculture. American Journal of Agricultural and Biological Science, 4 (2), 105, 2009.

14. CIOFFO G.D., ANSOMS A., MURISON J. Modernising agriculture through a "new" Green Revolution: the limits of the Crop Intensification Programme in Rwanda. Review of African Political Economy, 43 (148), 277, 2016.

15. ERIN O.S., JILL L., C.-H. Evaluating the long-term impacts of promoting "green" agriculture in the Amazon. Agricultural Economics, 46, 83, 2015.

16. HUANG D.J., LAI Z.Q., LI H. Research on the theoretical framework and action mechanism of eco-innovation in agriculture enterprises. Economy Ecological, 32 (9), 110, 2016.

17. JAMES A.T., LAURENS K., TONI W., TRACY N., JULIE E.-H., ALEC M., NEELS B. Unpacking systemic innovation capacity as strategic ambidexterity: How projects dynamically configure capabilities for agricultural innovation. Land Use Policy, 68, 503, 2017.

18. FUSSLER C. Driving Eco-innovation: A Breakthrough Discipline for Innovation and Sustainability. Pitman Publishing. 1996.

19. KESIDOU E., DEMIREL P. On the drivers of ecoinnovations: Empirical evidence from the UK. Research Policy, 41 (5), 862, 2012.

20. REID A., MiIEDZINSKI M. Eco-innovation. Final report for sectorial innovation watch. Technopolis, 3 (May), 1, 2008.

21. ANGELA T., LOURDES M.-M., MARLA A.D. Drivers of different types of eco-innovation in European SMEs. Ecological Economics, 92, 25, 2013.

22. OTSUKA K., KIJIMA Y. Technology policies for a green revolution and agricultural transformation in Africa. Journal of African Economies, 19 (SUPPL. 2), 60, 2010.

23. SANDERS R. A market road to sustainable agriculture? Ecological agriculture, green food and organic agriculture in China. Development and Change, 37 (1), 201, 2006.

24. LI X.J., WU W.L., LI Z.F. Development of China green food industrialization: Its theory and practice. Chinese Journal of Ecology, 24 (12), 1513, 2005.

25. FRANCIS C.A. Greening of agriculture for long-term sustainability. Agronomy Journal, 96 (5), 1211, 2004.

26. DONG Y., MU Y.Y., ITO S. Endogenous agricultural technology diffusion with factor structural changes in China. Journal of the Faculty of Agriculture, Kyushu University, 60 (2), 519, 2015. 
27. GU J., ZOU Y.H., WANG J.F. Application situation and development strategy of modern information technology in agricultural science and technology achievement transformation in China. Journal of Southern Agriculture, 45 (10), 1746, 2014.

28. WANG D.S. Development status and future prospects of green agriculture. Chinese Journal of Agricultural Resources and Regional Planning, 37 (2), 226, 2016.

29. ROBERTSON T.S., GATIGNON H. Competitive effects on technology diffusion. Journal of Marketing, 50 (3), 1, 2013.

30. BLAUT J. M. Diffusionism: A Uniformitarian Critique. Annals of the Association of American Geographers, 77 (1), 30, 1987.

31. CHEN Z., SONG S.F. Efficiency and technology gap in China's agriculture: A regional meta-frontier analysis. China Economic Review, 19 (2), 287, 2008.

32. YING R.Y., ZHOU L., HU W.Y., PAN D. Agricultural technical education and agrochemical use by rice farmers in China. Agribusiness, 33 (4), 522, 2017.

33. LUO L.G., WANG Y., QIN L. H. Incentives for promoting agricultural clean production technologies in China. Journal of Cleaner Production, 74, 54, 2014.

34. ZHANG J.Y., YU Y.H. Technology diffusion, government policy and agricultural sustainable development. In Proceedings of 2007 International Conference on Management Science and Engineering, ICMSE'07 (14 $\left.{ }^{\text {th }}\right)$ 2214, 2008

35. LV Y.H., ZHANG R. Ecological Agriculture Technology in Urban Agriculture. Advanced Materials Research, 224, 38, 2011.

36. BRECHET T., LY S. The many traps of green technology promotion. Environmental Economics and Policy Studies, 15 (1), 73, 2013.

37. KONG D.J., FENG Q., ZHOU Y., XUE L. Local implementation for green-manufacturing technology diffusion policy in China: From the user firms' perspectives. Journal of Cleaner Production, 129, 113, 2016.

38. SANGUI W. The diffusion of agricultural technology in poor areas of south-west China: the role of farmer's organizations and village governments. China Information, 10 (3/4), 141, 1996.

39. HE Z.L., WONG P.-K. Exploration vs. Exploitation: An Empirical Test of the Ambidexterity Hypothesis. Organization Science, 15 (4), 481, 2004.

40. FRIEDMAN D. On Economic Applications of Evolutionary Game Theory. Journal of Evolutionary Economics, 8 (1), 15, 1998.

41. ZHAO D.W. Game analysis of green agriculture development in China. Statistics and Decision, 12 (12), 75, 2013.

42. ZHAO L.M., WANG H.X. Game analysis between government and farmer at the beginning of green agriculture. Journal of Chinese Agricultural Mechanization, 4 (4), 23, 2007.

43. CAO Q., GEDAJLOVIC E., ZHANG H.P. Unpacking Organizational Ambidexterity: Dimensions, Contingencies, and Synergistic Effects. Organization Science, 20 (4), 781, 2009.

44. O.WILSON E. Sociobiology: The New Synthesis. Social Forces 55. Harvard University Press, United States. 1975.

45. LEE J. Symbiosis. Symbiosis, 4, 489, 2004.

46. GIBSON C.B., BIRKINSHAW J. The antecedents, consequences, and mediating role of organizational ambidexterity. Academy of Management Journal, 47 (2), 209, 2004.

47. SARKAR M.K. Climate Change and Green Technology for Enduring Agriculture. American Journal of Agriculture and Forestry, 2 (1), 7, 2014.

48. LIN L., ZHOU D.Y., MA C.X. Green food industry in China: development, problems and policies. Renewable Agriculture and Food Systems, 25 (1), 69, 2010.

49. MOR S., MANCHANDA C.K., KANSAL S.K., RAVINDRA K. Nanosilica extraction from processed agricultural residue using green technology. Journal of Cleaner Production, 143, 1284, 2017.

50. WU L.Y., QI Z.H., HUANG W.H., ZHU M., HU J. Pig farmers' willingness to adopt the ecological breeding mode and the influencing factors. Research of Agricultural Modernization, 38 (2), 284, 2017.

51. SIDDIQUI M.W. Eco-Friendly Technology for Postharvest Produce Quality. Elsevier Ltd. 2016.

52. LIU H.B., McCARTHY B., CHEN T.Z. Green Food Consumption in China: Segmentation Based on Attitudes Toward Food Safety. Journal of International Food and Agribusiness Marketing, 28 (4), 346, 2016.

53. YU X.H., GAO Z.F., ZENG Y.C. Willingness to pay for the "Green Food" in China. Food Policy, 45, 80, 2014.

54. ZHANG C.T., LIU L.P. Research on coordination mechanism in three-level green supply chain under noncooperative game. Applied Mathematical Modelling, 37 (5), 3369, 2013

55. ZHANG X.L., BAO H.J., SKITMORE M. The land hoarding and land inspector dilemma in China: An evolutionary game theoretic perspective. Habitat International, 46, 187, 2015.

56. CHEN S. H. An Evolutionary Game Study of an Ecological Industry Chain Based on Multi-Agent Simulation: A Case Study of the Poyang Lake Eco-Economic Zone. Sustainability, 9 (7), 1165, 2017.

57. LI J., DU W.H., YANG F.M., HUA G.W. Evolutionary Game Analysis of Remanufacturing Closed-Loop Supply Chain with Asymmetric Information. Sustainability, 6 (9), 6312, 2014.

58. FRIEDMAN D. Evolutionary Games in Economics. Econometrica, 59 (3), 637, 1991. 